\title{
Mathematics Teachers' Professional Identity Development in Communities of Practice: Reifications of Proportional Reasoning Teaching
}

\author{
Desenvolvimento da Identidade Profissional de Professores de Matemática \\ em Comunidades de Prática: Reificações do Ensino do Raciocínio \\ Proporcional
}

Márcia Cristina de Costa Trindade Cyrino*

\begin{abstract}
In the last decade, the Study and Research Group on the Education of Teachers who teach Math - GEPEFOPEM (Brazil) investigated teacher education groups constituted as Communities of Practice - CoPs. The objective of this paper is to discuss the focus of one of these CoPs when working with Proportional Reasoning and the practice elements of four CoPs, which promoted the development of their members' professional identity. The data was collected through an analysis of meaning negotiation processes, mobilized knowledge and the CoPs dynamics based on different groups interactions and written production of their members. The analysis showed that selfknowledge, beliefs and concepts, professional knowledge, vulnerability, and the sense of agency became the focal points of the CoPs during the study of proportional reasoning as well as the practice elements of the four CoPs that promoted the professional identity development of, namely: shared repertoires, reports and discussions on their pedagogical practices, the existence of an open and flexible work plan, the opportunity to discuss their written productions, vulnerability experiences, the search for a sense of agency balance, connections among observations and empirical interpretations and a broader theoretical background, reports and discussions on previous meetings. Factors such as respect, trust, challenge, solidarity, projects negotiations, dynamics and actions, valorization of the singularities, and professional practices of teachers are essential for the constitution of the professional identity of these professionals and for the cultivation and maintenance of these groups.
\end{abstract}

Keywords: Teachers' Professional Identity. Mathematics Teachers Education. Communities of Practice. Proportional Reasoning.

\section{Resumo}

Na última década o Grupo de Estudo e Pesquisa sobre Formação de Professores que Ensinam Matemática GEPEFOPEM (Brasil) investigou grupos de formação de professores que se constituíram como Comunidades de Prática - CoPs. Este artigo tem como objetivos discutir o que se tornou ponto de enfoque na prática de uma dessas CoPs no trabalho com o Raciocínio Proporcional e elementos da prática de quatro CoPs que promoveram o desenvolvimento da identidade profissional de seus membros. Para obtenção das informações analisamos os processos de negociação de significados, os conhecimentos mobilizados, e a dinâmica das CoPs a partir das interações nos diferentes grupos e da produção escrita de seus membros. A análise evidenciou que o

* PhD in Education from Universidade de São Paulo (USP). Professor at the Mathematics Department and Graduate Program in Science and Math Education from Universidade Estadual de Londrina (UEL), Londrina, Paraná, Brazil. Address for correspondence: Rua Caracas, 377, apto 2103, Jd. Santa Rosa, CEP 86050-070, Londrina/Paraná, Brasil. E-mail: marciacyrino@uel.br 
autoconhecimento, as crenças e concepções, os conhecimento profissionais, a vulnerabilidade e o sentido de agência se tornaram pontos de enfoque da $\mathrm{CoP}$ no estudo do raciocínio proporcional, bem com os elementos da prática das quatro CoPs que promoveram o desenvolvimento da identidade profissional, nomeadamente: os repertórios compartilhados, relatos e discussões de suas práticas pedagógicas, existência de um plano de trabalho aberto e flexível, oportunidade de discutir suas produções escritas, experiências de vulnerabilidade, busca de equilíbrio do sentido de agência, conexões entre as observações e interpretações empíricas e um referencial teórico mais amplo, relatos e discussões de encontros anteriores. Fatores como respeito, confiança, desafio, solidariedade, negociação dos empreendimentos, dinâmicas e ações, valorização das singularidades e das práticas profissionais dos professores se mostram férteis e fundamentais à constituição da identidade profissional desses professores e ao cultivo e manutenção desses grupos.

Palavras-chave: Identidade Profissional de Professores. Formação de Professores que Ensinam Matemática. Comunidades de Prática. Raciocínio Proporcional.

\section{Introduction}

The number of studies on the mathematics teacher education has increased in the last years; especially those in search for professional development programs that prepare teachers to understand and face current educational challenges (SOWDER, 2007; PONTE; CHAPMAN, 2008; SIMON, 2008; JAWORSKI, 2011). Several are the challenges imposed on the teacher, namely the processes of teaching and learning, the tension between epistemological and cognitive plans, the complexity and diversity of the classroom, the construction and implementation of a curriculum to meet current social demands and the new teacher's roles.

These studies show the complexity of the developmental process and the need to think about the interactions among the different intrinsic aspects of teacher education programs, such as: mathematics knowledge; mathematics teaching knowledge; the understanding of how students learn; the development of teachers' professional identity; future teachers' knowledge, expectations, conceptions and interests; teachers educators' characteristics, knowledge and concepts as well as of other participants of the development program; objectives, evaluation criteria, curriculum and program organization; objectives and organization of the educational system, pedagogical materials and educational research, among others.

In Brazil, researchers who participate in teacher development programs have worked to understand and articulate these aspects in order to promote learning and professional identity development opportunities for future teachers and for teachers who teach mathematics. According to Cyrino (2009, p. 95), “[...] the efforts of this area are targeted [...] to give a new direction to the development of these professional taking into consideration the demands of contemporary society and educational systems". 
The Study and Research Group on the Education of Math teachers - Gepefopem, based at Universidade Estadual de Londrina (UEL) - has investigated, in the last twelve years, mathematics teachers initial and continuing education perspectives to identify factors that may intervene in the process of constituting the identity of these professionals. The analysis of these perspectives showed the little efficacy of teacher education programs based on training courses, since they hardly ever take into account the different needs of the teacher's practice.

Considering that proposals for teacher education programs must take into account the singularities of the teacher's teaching practices and the factors that affect these practices, the Gepefopem proposed, starting in 2008, the creation of study groups involving in-service mathematics teachers, future mathematics teachers and researchers, to constitute Communities of Practice - CoPs (WENGER, 1998), and assumed them as investigation scenarios.

The present article discusses the focus of one of these CoPs during their work on Proportional Reasoning and the practice elements of four CoPs which promoted the development of their members' professional identity. To do so, the theoretical aspects related to teacher education and professional identity development in Communities of Practice is introduced, together with those related to Proportional Reasoning. Next, the methodological approaches adopted by this work and the analyses that led us to make some considerations on the theme of this article are described.

\section{Teacher education in Communities of Practice and professional identity development}

Communities of practice ${ }^{1}$ of teachers who teach mathematics have been presented in the literature as a rich and fertile soil to explore the learning processes of future teachers and teachers who teach mathematics (LLINARES, 2002; GRAVEN, 2005; CYRINO; CALDEIRA, 2011; NAGY; CYRINO, 2014; GARCIA, 2014; OLIVEIRA, 2014).

According to Wenger, McDermott and Synder (2002), a CoP presuppose the existence of three fundamental and structural aspects: a domain of knowledge, a community of people and the shared practice. The domain is the element that mobilizes members CoP to contribute and participate in the community in the search for affirmation of its objectives, actions, initiatives, and enhancement of its members; it is the element that legitimizes the existence of the community. The community refers to the environment in which people interact, learn and

\footnotetext{
${ }^{1}$ For more information read (WENGER, 1998; WENGER; MCDERMOTT; SNYDER, 2002).
} 
build relationships; it is the "[...] the social fabric of learning" (p.28). The practice is defined as "a set of frameworks, ideas, tools, information, styles, language, stories, and documents that community members share. Whereas the domain denotes the topic the community focuses on, the practice is the specific knowledge the community develops, shares, and maintains." (p.29). As the practice of coherence source community, Wenger (1998) proposes three interrelated dimensions: mutual engagement, joint enterprise, and shared repertoire of ways of doing things.

Graven and Lerman (2003) emphasize that, although research on mathematics teachers' education has created contexts that enable to learning and describe what teachers learn in social terms, little studies has been done to explain how those contexts enable learning. Therefore, GEPEFOPEM decided to analyze the elements of the practice of Communities of Practice of teachers who teach mathematics that promote learning and, consequently, the development of teachers' professional identity.

The development of the professional identity is a complex process that includes the personal, professional, intellectual, moral and political aspects of the groups to which the subjects are involved (BEIJAARD et al., 2004; KELCHTERMANS, 2009; PONTE; CHAPMAN, 2008; OLIVEIRA; CYRINO, 2011). It consists not only of what others think or say about us, although that is also part of our way of living, but also of how we see ourselves and our capacity to reflect on our experience. According to Wenger (1998) "identity in practice is defined socially not merely because it is reified in a social discourse of the self and of social categories, but also because it is produced as a lived experience of participation in specific communities (p. 151)".

We perceive the teacher's professional identity as a set of interconnected beliefs/concepts and knowledge about his/her work, associated to autonomy (vulnerability and sense of agency) and political commitment. The set of beliefs/concepts teachers have about themselves and their profession, of what it means to be "an excellent teacher" and the type of teacher they want to be, among other things, are interconnected and affect the knowledge they develop about their work. This knowledge includes content knowledge, general pedagogical knowledge and pedagogical content knowledge ${ }^{2}$, curriculum knowledge, knowledge about the students, knowledge about the objectives, purposes and educational values and their historical and philosophical foundations, knowledge of the educational context (SHULMAN, 1986, 1987) and an understanding of the classroom practices.

\footnotetext{
${ }^{2}$ An amalgam between pedagogical knowledge and discipline knowledge (SHULMAN, 1986).
} 
To develop the teacher's professional identity, a space in their education process is necessary to favor the emergence of vulnerabilities and the appropriation of the values and norms of the profession. Oliveira and Cyrino (2011) highlight the fact that this vulnerability is not something that weakens and paralyzes,

[...] but one that allows us to hold back for some more or less long and more or less frequent moments, our certainties and convictions, which makes us question ourselves. It is also vulnerability in the sense of exposing ourselves to others and, consequently, becoming "the target of criticism and argumentations" (p. 112).

It is the kind of vulnerability that allows developing teachers ${ }^{3}$ to recognize their difficulties and limitations; deal with the resulting conflicts and dilemmas related to the teaching practice and recognize mistakes as mutual learning opportunities. To prevent this vulnerability to turn into weaknesses, it is necessary to implement actions that, by using instituted spaces, promote the rethinking of their practices, beliefs/concepts and offer them opportunities to develop knowledge to overcome their difficulties and limitations. These spaces must help develop the (future) teacher's capacity to face any vulnerability with a sense of agency (OLIVEIRA; CYRINO, 2011).

Within the social perspective of learning, this agency stops being regarded as an individual capacity or quality to be evaluated as a measure by the interaction between the individual component (attributes and inclinations) and the tools and structures of the social scenario. "This way, it makes sense to talk about a "mediated agency" (OLIVEIRA; CYRINO, 2011, p. 114). During the development of teachers in Communities of Practice, their members have the opportunity to reflect on and interpret the social requisites and norms of their (future) practice, as well as act upon different contexts in which these practices operate (regardless of the embarrassments), and, consequently, develop a sense of agency as they position themselves and develop autonomy, "by taking into account their perspectives, knowledge and potentials" (OLIVEIRA; CYRINO, 2011, p. 114).

For Wenger (1998), an identity is developed in social contexts (CoPs) through the ways their members negotiate meanings. An identity is "a way of talking about how learning changes who we are and creates personal histories of becoming in the context of our communities" (WENGER, 1998, p. 5). Learning is seen as a social practice which takes place in the context of our routine experiences with the world in a process of meaning negotiation. Meaning negotiation presupposes an interaction between two other processes: the participation process and the reification process.

\footnotetext{
${ }^{3}$ Every time we refer to a developing teacher or a teacher in process of development we are considering teachers and future teachers.
} 
By making a parallel between practice and identity, Wenger (1998) states that "[ [... developing a practice requires the formation of a community whose members can engage with one another and thus acknowledge each other as participants" (p. 149). This process of recognition produces negotiation regarding the way of being of the people involved in the community, i.e., it involves a negotiation of its members' identities. It is impossible to think of identity and practice in isolation, because as shown in Table 1 "identity and practices are mirror images of each other" (WENGER, 1998, p. 149) (Table 1).

Table 1 - Parallel between practice and identity; Source: (WENGER, 1998, p. 150)

\begin{tabular}{|l|l|}
\hline practice as ... & Identity as ... \\
\hline $\begin{array}{l}\text { negotiation of meaning (in terms of participation } \\
\text { and reification) }\end{array}$ & $\begin{array}{l}\text { negotiated experience of self (in terms of } \\
\text { participation and reification) }\end{array}$ \\
\hline community & membership \\
\hline shared history of learning & learning trajectory \\
\hline boundary and landscape & nexus of multi-membership \\
\hline constellations & belonging defined globally but experienced locally \\
\hline
\end{tabular}

Thus, it is necessary to consider the social groups in which we are involved, the relations we establish in them, the activities developed, the type of resources used and the stories that are shared and constructed. Learning is seen as a permanent process of constituting an identity of those who participate in a $\mathrm{CoP}$, in order to deal with the demands/problems inherent to the teachers' pedagogical act. In this paper, we identified some learning experiences related to Proportional Reasoning based on what has become the focus in the practice of one of the CoPs which we investigated.

\section{Proportional reasoning}

Proportional reasoning can be used in problem-solving inside and outside the school context. In the school context, proportional reasoning is considered one of the most relevant points in arithmetic learning, and the basis for more complex mathematical concepts involving proportion/proportionality in Geometry and Algebra, e.g.: to investigate proportionality surfaces, to examine properties of similar triangles, to investigate scaling problems, to examine number patterns, to translate the algebraic representation to a graphical representation, to define trigonometric functions.

Proportional reasoning can be conceptualized in these steps: identification of two extensive variables that are applicable, recognition of the rate of intensive variable whose constancy determines the linear function, and application of the given data and relationships to find (i) an additional value for one extensive variable (missing value problems) or (ii) comparison of two values of the intensive variable computed from the data (comparison problem). (KARPLUS; PULOS; STAGE, p. 219, 1983). 
According to Cai and Sun (2004) proportional reasoning is an important road for the development of algebraic reasoning and for the students' understanding of the meaning of functions. However, Proportional Reasoning cannot be adopted as a synonym for proportionality but as a necessary condition for the comprehension of contexts and mathematics applications that involve proportion/proportionality (LESH; POST; BEHR, 1988). The mobilization of Proportional Reasoning may happen during the development of strategies and freer procedures, without being attached to formulas or algebraic resources such as the rule of three when identifying multiplicative relations among numerical quantities in a problem and when selecting, organizing and making explicit quantities that covariate among themselves as well as those that remain constant, among others. The work with proportionality should not be restricted to the use of algebraic resources in a mechanical fashion, depending on the memorization of rules and formulas.

\footnotetext{
Proportional reasoning refers to detecting, expressing, analyzing, explaining, and providing evidence in support of assertions about proportional relationships. The word reasoning further suggests that we use common sense, good judgment, and a thoughtful approach to problem-solving, rather than plucking numbers from word problems and blindly applying rules and operations. (LAMON, 2005, p. 4).
}

Proportional Reasoning involves covariance and invariance notions and multiplicative comparisons between ratios, and requires the capacity to interpret, store and process a set of information that mobilizes quantitative and qualitative aspects of knowledge (LESH; POST; BEHR, 1988; CRAMER; POST; BEHR, 1989). Among the quantitative aspects is the ability to solve mathematical algorithms correctly, think of numerical quantities in relative terms, conceive ratio as a constant relation (even with the covariation of the quantities that generated it). The qualitative aspects, on the other hand, involve the capacity to identify situations in which numerical quantities relate in a multiplicative and not additive way; the capacity to interpret, relate and analyze in a conscious way these quantities and the numerical results found in the solution of problems, assessing pertinence of these values, their dimensions and meanings within the context of problems; the capacity to identify and distinguish situations that involve relations which are directly/inversely proportional to those that do not present such types of multiplicative relations.

For Lamon (2005), proportional reasoning involves a minimum set of concepts, operations, contexts, representations and forms of thinking which are widely interrelated (forming a network - Figure 1) and key to its development, namely: the different interpretations of the rational number represented by the form $\frac{a}{b}$; measurement; invariance and covariance relations; relative thinking; unitization (composing and decomposing of units of several situations types); sharing and comparison and up and down reasoning. 


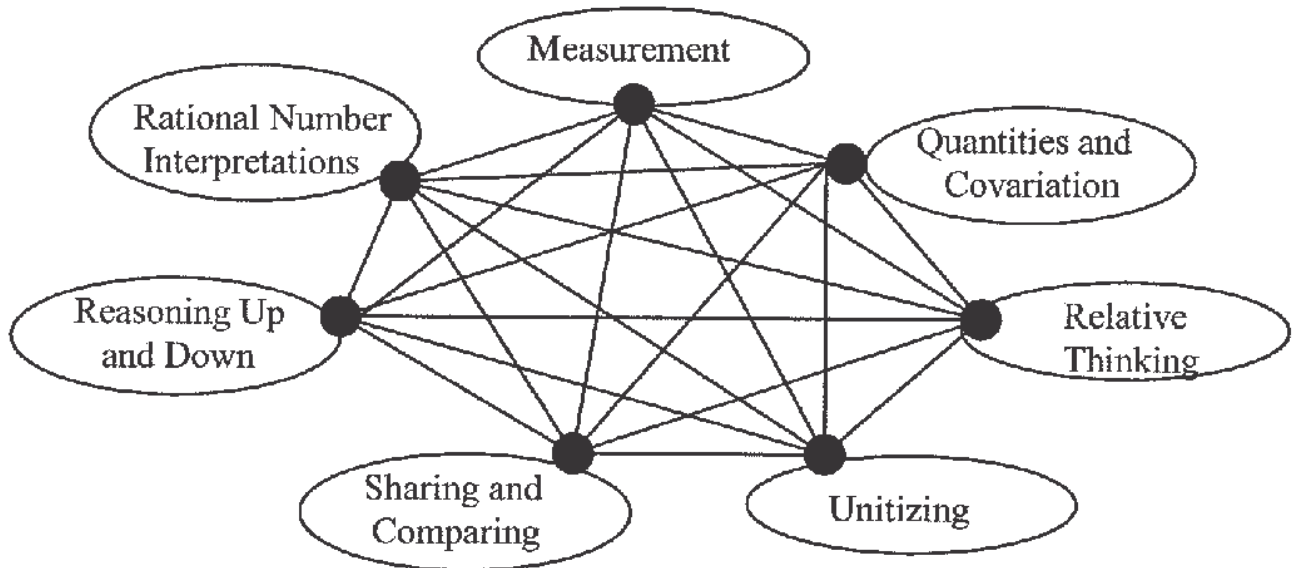

Figure 1 - Elements necessary for the development of proportional reasoning; Source: (LAMON, 2005, p.9)

By presenting and relating these elements necessary for the development of proportional reasoning, Lamon (2005) does not overlook the broad and intricate process of constitution of mathematical knowledge. Although they are presented in Fig. 1 with dots (knots), they represent different ideas and concepts that have an impact on the whole network.

Reasoning proportionally involves the understanding:

- of meanings underlying the fraction representation $\left(\frac{a}{b}\right.$ with $\left.\mathrm{b} \neq 0\right)$ of rational numbers, which are associated to different contexts - part-whole relationship, measurement, quotient, ratio or rate, operator (KIEREN, 1980) -, involving first order relations of the part-part type (ratio, e.g.) or part-whole type;

- of second order relations that can be established between two or more of these representations of the type $\frac{a}{b}=\frac{c}{d}$, with $\mathrm{b} \neq 0$ and $\mathrm{d} \neq 0$ (proportionality relations, equivalence or comparisons involving the notion of order: greater, smaller, the same).

These different interpretations of fraction registration may be seen as varied forms of measurements. According to Lamon (2005):

- a part-whole fraction measures the multiplicative relationship of a part to the whole to which it belongs;

- a ratio measures relative magnitude; a rate such as speed is a quantification of motion;

- a quotient is a measure of how much 1 person receives when $m$ people share $n$ objects;

- an operator is a measure of some change in a quantity from a prior state;

- as a measure, a rational number directly quantifies a quality such as length or area. (LAMON, 2005, p.40).

The understanding of the measurement idea is based on three important mathematical principles (LAMON, 2005):

i) the compensatory principle: the smaller the considered unit the greatest the amount of units needed to measure something and vice-versa; 
ii) the approximation principle: a measure is always an approximation, therefore it is possible to manipulate measurement units to make them as precise as necessary;

iii)the recursive partitioning principle: a measurement unit can be subdivided into smaller parts and equal parts, as many times as needed to get a precise measure.

This measure/measurement idea is connected to relative thinking (another knot in the network, Figure 1). By comparing measures, as in the case of live beings heights in two distinct moments of their growth, it is possible to identify the occurrence of variations in the measurements in relative and absolute terms: the difference between the final and initial height of a tree results in a numerical quantity, a linear measure, indicated by a determined unity such as centimeters, millimeters, etc. (an absolute variation). However, the comparison established between this linear quantity, registered in two distinct tree growth moments and its initial height results in a growth rate, a comparison indicating a relative variation, signaled by units such as the percentage (\%).

According to Lamon (2005), to reason in relative terms demands greater abstraction from individuals than to reason in absolute terms (reasoning based on visualization, counting and the direct measurement of quantities). Through relative thinking, individuals are capable of measuring more complex and abstract quantities and those which cannot be measured directly with the use of specific instruments or immediate counting. They are quantities resulting from comparisons/relations between quantities of sometimes distinct nature such as speed, density, inclinations, concentration, among others.

The characterization of "Quantities and Covariation" is related to the capacity to identify and measure quantities and to notice how these quantities vary (co-vary) when related. The process of identifying, quantifying quantities (direct or indirectly through relative thinking/thinking) and of analyzing which ones go (or not) under alterations (which ones covary or remain invariant), and how these alterations take place (in a multiplicative way, directly or inversely proportional), promotes the development of more powerful forms of reasoning (such as the Proportional Reasoning) which go beyond recognition of obvious information in analyzed contexts.

The process of unitization ${ }^{4}$ is directly related to the process of reasoning up and down and to the concept of fractions equivalence. The unitization can be characterized as a process of reorganizing the quantities with which one works, (re)grouping them in order to develop

\footnotetext{
${ }^{4}$ Unitizing refers to the process of constructing chunks in terms of which to think about a given commodity (LAMON, 2005, p. 78).
} 
subgroups that continue to represent the same total quantities, i.e., the wholes or referential units remain the same but are represented by different fraction forms, which means" [...] to conceptualize a quantity in terms many different-sized pieces" (LAMON, 2005, p. 80). For this author, to unitize is a subjective and natural process for individuals, which must be constantly provoked in order to promote greater reasoning freedom.

To unitize quantities, maintaining their proportionality relations, is developed through reasoning up and down, a mental procedure that involves calculating in a progressive way, from any fraction, the proportionality relations equivalent to the whole (referential unit) and then to find proportional relations for the any other fractions of this whole, based on the already found relations or vice-versa.

The registration of numerical quantities in fraction representation is rooted in the equal sharing or division idea, in the act of unit partitioning, being discrete or continuous, into disjointed, finite and equal sections, i.e., the divided parts do not superpose one another, and all of them being result of the partition are part of the unit (LAMON, 2005). This process is essential to understand the fraction representation of rational numbers, decimal representations and the concept of equivalence between fractions. The idea to realize divisions in a unit and then establishing comparisons between the quantities obtaining by these divisions is also related to measurement.

Considering the importance of proportional reasoning for mathematics and for the development of problem-solving strategies which go beyond the mechanical reproduction of formulas, its study was one of the projects negotiated by one of the teacher development CoPs, which will be used as an example in this paper to show the elements of the practice that promoted the development of the professional identity of its members.

\section{Methodological aspects}

The design of this study combines intervention and research, characterized as intervention research (KRAINER, 2003). For the author, this type of research is "[...] most of the times process-oriented and context-limited, generated by a continuous interaction and communication with the practice" (p. 98). In an intervention research, researchers neither position themselves outside the practice nor investigate their own practice in order to improve it. The researcher/ teacher educator plays a double role: that of an investigator who aims at "increasing his/her own understanding and theoretical knowledge to be able to share them with the scientific community" (p. 97) and that of a teacher educator who aims at developing participants through practice. 
The current study deals with the elements of practice of four study groups, constituted as Communities of Practice of teachers who teach mathematics, that offer learning and professional identity development opportunities for their members. These CoPs were organized in four cities in the State of Paraná, and each one counts on the participation of six to nine Basic Education teachers, one to four future teachers and one to three researchers ${ }^{5}$.

The dynamics assumed in each group (community) promoted the creation of CoPs, because the practices developed by the participants legitimized and promoted the engagement, respect and mutual trust, sharing experiences and knowledge, trading in shares and enterprises, related to the themes discussed in each group (domain). I.e., each group of teachers who teach mathematics (community) was willing to discuss a subject (domain) in an education context (practice). To this end, each group established mutual engagements in the realization of the joint enterprise, which required a shared repertoire.

In regards to data collection methods, in all CoPs audio registration of the sessions, (future) teachers' written records (tasks' solutions and, reflections on meetings in a notebook or moodle platform) and field notes produced by the teacher educators were used.

Data analysis was continuous (GRAVEMEIJER; COBB, 2006) and helped assess and guide discussions and identify the participants' learning experiences through meaning negotiation processes. The search for elements that offer opportunities for these learnings and, consequently, the constitution of the participants' professional identity was adopted as a parameter for the analysis.

To exemplify the CoPs' dynamics, the meaning negotiation processes and the knowledge mobilized, to identify professional identity aspects, the next section introduces a practice episode from the "Community of Practice of Teachers who Learn and Teach Math - CoP PAEM"6 (which meets more than four years), coordinated by Tânia Marli Rocha Garcia, as part of the joint enterprise Proportional Reasoning Study, more specifically in actions 1 and 4 (see below), which involved the solution and discussion of proportion/proportionality problems, the analysis of some of the used strategies and the teachers' justifications, with the support of the literature.

The joint enterprise "Proportional Reasoning Study", which lasted 10 months, included five linear actions that did not follow a linear trajectory. In action 1, members of the

\footnotetext{
${ }^{5}$ In the context of these teacher development practices, these researchers were called teacher educators, namely: Márcia Cristina de Costa Trindade Cyrino; Márcia Cristina Nagy; Cristina Cirino de Jesus; Loreni Aparecida Ferreira Baldini; Tânia Marli Rocha Garcia; Lais Maria Costa Pires de Oliveira; Márcio Roberto Rocha.

${ }^{6}$ CoP-PAEM was one of the groups that participated in the project "Math Education of Teachers who Teach Math" as part of the OBEDUC/CAPES Observatory Program.
} 
community solved the problems proposed by the teacher educator, which involved proportion/proportionality, and discussed resolution strategies collectively. The teacher educator challenged the participants to use strategies distinct from "the rule of three algorithm" they normally used. In action 2, as suggested by the CoP members, three texts on proportional reasoning were studied including: the key structures involved in its development; the role of the understanding of the different rational number interpretations; the importance of proportional reasoning for the development of the students' mathematical thinking and the comprehension of abstract mathematical concepts. In action 3, group participants were challenged to propose problems involving proportion/proportionality. These problems were solved and discussed collectively, emphasizing solution strategies, the problem statement and other mathematical ideas involved. In action 4, the participants discussed some strategies and justifications presented in action 1 based on the synthesis prepared by the teacher educators with the support of the literature (action 2). In action 5, each participant had to propose a problem with the potential to mobilize proportional reasoning and coordinate discussions on the resolution strategies presented by the CoP members.

During the period in which the data were collected, the CoP-PAEM was constituted of six Basic Education teachers (Bia, Clea, Eva, Tina, Iara e Ada) ${ }^{7}$, a future mathematics teacher (Luiz) and three researchers (Tânia, Laís and Márcio). During the analysis of this episode, the learning trajectories of the community members were discussed through the forms of participation (actions and interactions) and reifications (contents, projections, interpretations) that they experienced during the process.

\section{CoP-PAEM in the study of Proportional Reasoning}

Action 4 was proposed by one of the teachers, Eva, and negotiated in the group. Based on the written productions and discussions in action 1, the teacher educator prepared a table with a synthesis of the strategies and justifications negotiated by the participants on five problems. The problems involved a wide variety of situations, such as missing value problems, rate speed, mixture, density, scaling, conversion, consumption, pricing. The present paper introduces the discussions originated from the synthesis of the work developed with one of

\footnotetext{
${ }^{7}$ The names used for the Basic Education teachers and future teachers are fictitious. The project was approved by the Ethics Committee of Universidade Estadual de Londrina.
} 
these problems, "The price of coffee", which although it is not exactly real was selected by the diversity of strategies and intensity of meaning negotiations that occurred.

Table 2 - Problem "The price of coffee"; Source: Adapted from (LAMON, 2005, p. 12-3) In a gourmet coffee shop, two types of beans are combined and sold as the House Blend. One bean sells for $\mathrm{R} \$ 8,00$ and the other for $\mathrm{R} \$ 14,00$. The shop owner mixes up a batch of $50 \mathrm{Kg}$ at a time and sells the House Blend for $\mathrm{R} \$ 10,00$. How many $\mathrm{Kg}$ of each kind of coffee go into the blend?

The problem statement represents a situation in which the comprehension of relative thinking and measurement is necessary after identifying the covariant identities (type 1 and type 2 beans). Table 3 shows the written records and respective description of strategies, followed by the justification for the different solutions discussed by the participants in Action 1.

Table 3 - Written records of solutions and description with justification; Source: Researchers (Meeting on July 3, 2012)

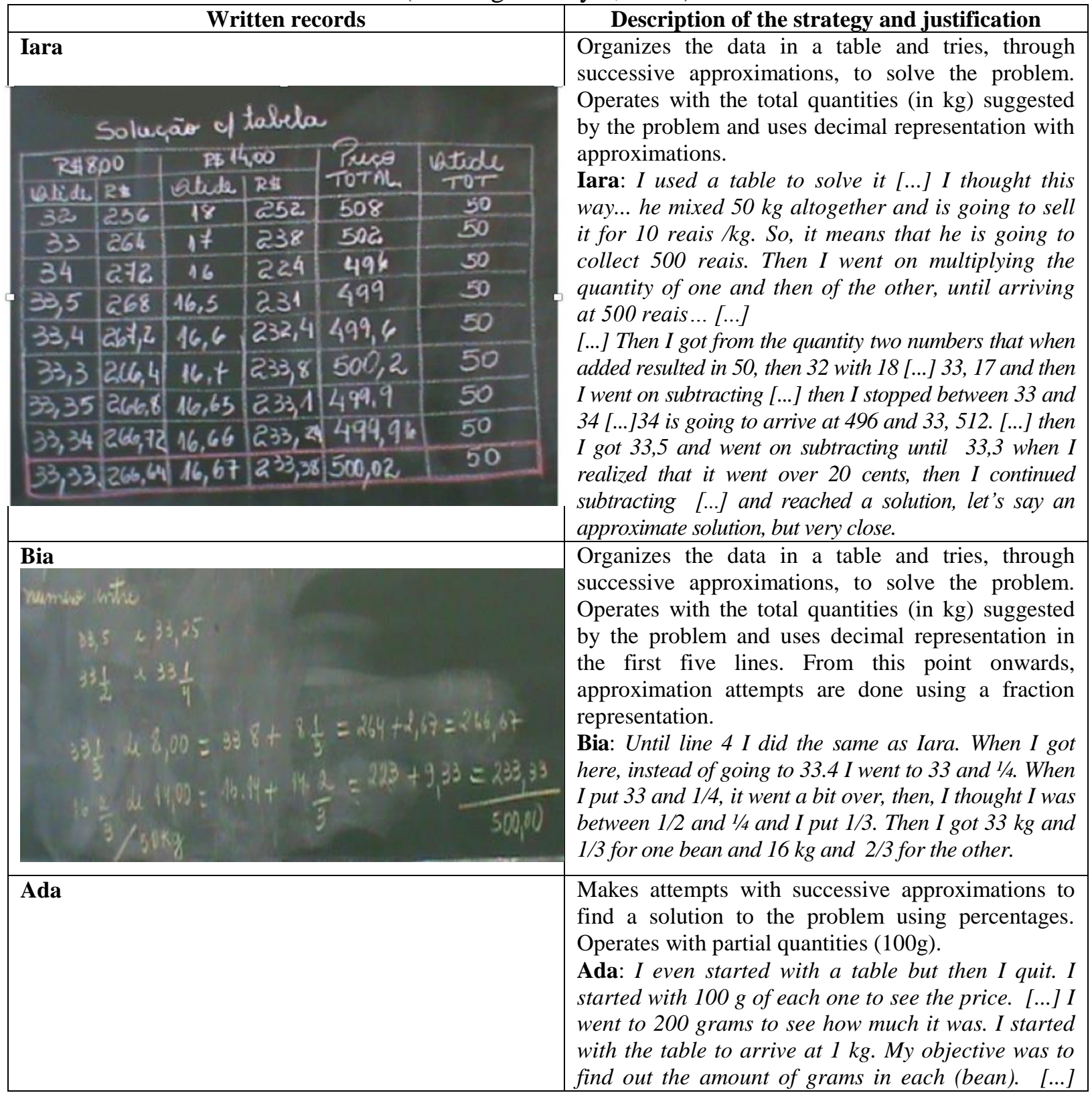




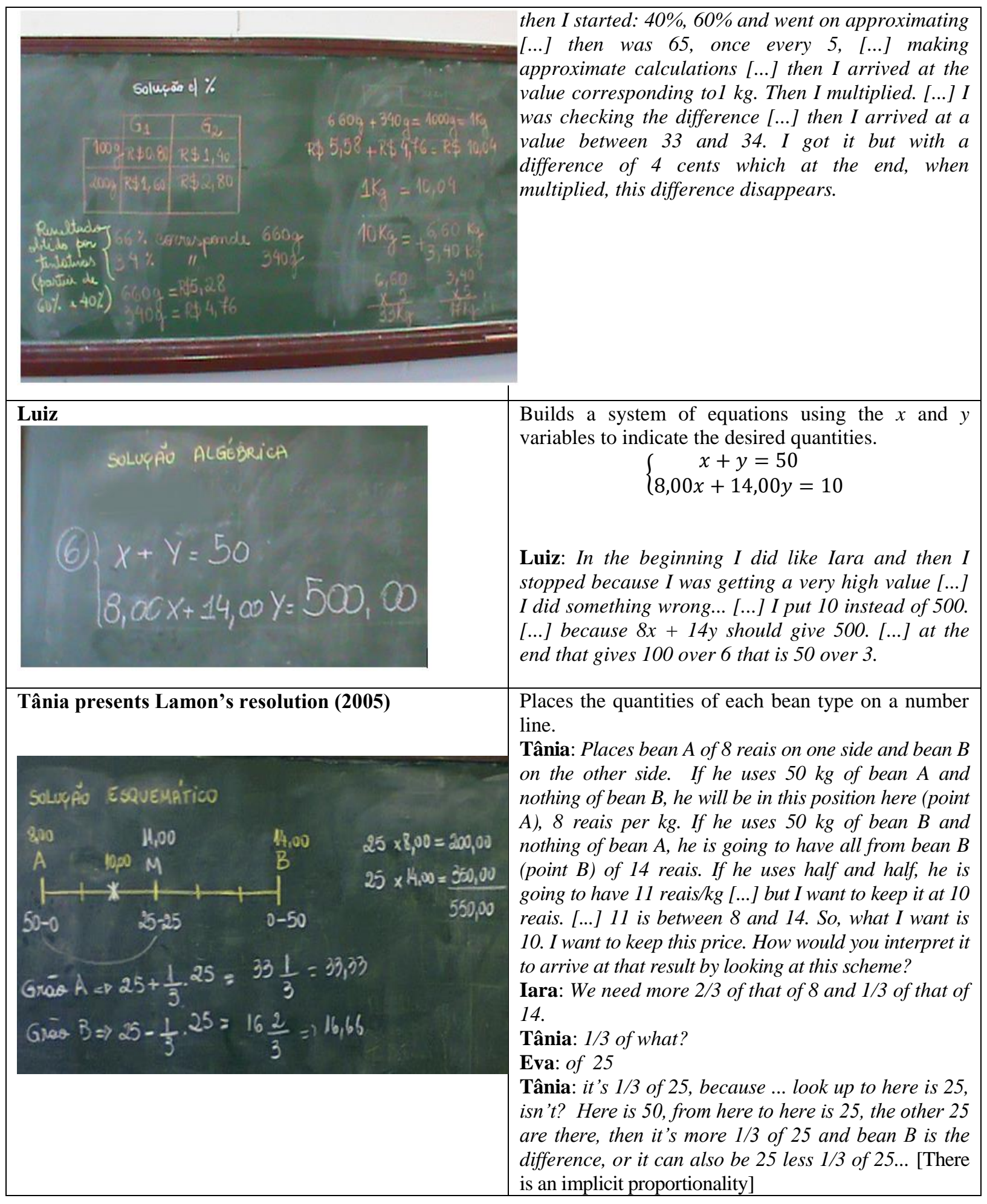

In action 4, a table similar to Table 3 was presented so that participants of the CoP and the teacher educator could analyze the strategies and justifications described and identify and highlight, in the resolutions and arguments, signs of Proportional Reasoning mobilization, supported by the literature. 
Table 4 systematizes some professional identity aspects that became the focus of the discussions in actions 1 to 4, taking into consideration what was reified and mobilized.

Table 4 - Aspects of the Teacher's Professional Identity mobilized by members of the CoPPAEM during the resolution and discussion of the problem "The price of coffee". Source: Researchers (Meetings realized on July 3, 2012 and April 23, 2013)

\begin{tabular}{|c|c|c|}
\hline $\begin{array}{l}\text { Aspects of the } \\
\text { Teacher's } \\
\text { Professional } \\
\text { Identity } \\
\end{array}$ & What was reified/ mobilized & Evidences \\
\hline \multirow{3}{*}{ Self-knowledge } & $\begin{array}{l}\text { Selfconfidence. } \\
\text { Self-esteem. } \\
\text { Self-image. }\end{array}$ & $\begin{array}{l}\text { Bia: I've got to tell you something: yesterday, } \\
\text { working with my students, I think it was the first } \\
\text { time I left the room like this, satisfied, you know? } \\
\text { [The students] understood, what is really fine is } \\
\text { that they understood!! [...] It was amazing! }\end{array}$ \\
\hline & $\begin{array}{l}\text { Acknowledgement of the fact } \\
\text { that the teacher needs to study. }\end{array}$ & $\begin{array}{l}\text { Ada: I think teachers don't have time to study [...] } \\
\text { because I'm having difficulty finding time to study } \\
\text { [...] We get stuck with [proportional] reasoning. } \\
\text { How are we going to develop this type of reasoning } \\
\text { if we don't study? }\end{array}$ \\
\hline & $\begin{array}{l}\text { Participation in the CoP-PAEM } \\
\text { as an emotional support for } \\
\text { teachers. }\end{array}$ & $\begin{array}{l}\text { Bia: I call these "therapy sessions" moments. } \\
\text { Eva: This sharing of ideas with colleagues [...] } \\
\text { seems to open up our minds, give more security. } \\
\text { Tina: It's really a "therapy session", we get nervous } \\
\text { sometimes [...] with things that happen at school and } \\
\text { with this conversation, we leave here more relaxed. }\end{array}$ \\
\hline $\begin{array}{l}\text { Beliefs } \\
\text { conceptions }\end{array}$ & Belief/Concepts change. & $\begin{array}{l}\text { Clea: Something I learned a lot was to look for } \\
\text { several ways to solve [a question]. Before I used to } \\
\text { see only one way of doing things. [...] Like with the } \\
\text { coffee problem, I never imagined I could solve the } \\
\text { problem that way. It's highly stimulating. }\end{array}$ \\
\hline \multirow[t]{3}{*}{$\begin{array}{l}\text { Professional } \\
\text { knowledge: } \\
\text { mathematics } \\
\text { specific knowledge }\end{array}$} & $\begin{array}{l}\text { Relative Reasoning and } \\
\text { measurement } \\
\text { Recursive partition principle: } \\
\text { to get a precise measurement it } \\
\text { is necessary to subdivide the } \\
\text { measurement unit into equal } \\
\text { and increasingly smaller } \\
\text { subunits. By dividing the unit in } \\
\text { smaller pieces a fraction will } \\
\text { appear. }\end{array}$ & $\begin{array}{l}\text { Tânia: What did Iara do after } 33,3 \text { ? } \\
\text { Bia: As she was looking for precision, she used } \\
\text { another decimal place, another measure [...] It was } \\
\text { refined. She went on partitioning: a tenth of a } \\
\text { kilogram, a hundredth of a kilo. } \\
\text { Tina: Iara used decimal register. And Bia used } \\
\text { fractions register. [...] This idea of knowing that it is } \\
\text { between } 1 / 2 \text { and } 1 / 4 \text { is a measurement idea, isn't it? } \\
\text { Bia: Then, when it arrived at } 33 \text { and a half with } 15 \\
\text { and a half we got } 499 \text { reais, I did } 33 \text { and } 250 \text {, then } \\
\text { it went over a bit; then I thought, it must be number } \\
\text { between } 33 \text { and } 1 / 2 \text { and } 33 \text { and } 1 / 4 \text {, then I tested } \\
\text { again with } 33 \text { and } 1 / 3 . . . \text { I arrived at } 500 \text { reais. }\end{array}$ \\
\hline & $\begin{array}{l}\text { Relative thinking and } \\
\text { measurement } \\
\text { Rational numbers density } \\
\text { property: allows increasingly } \\
\text { closer measurement } \\
\text { approximations. There is an } \\
\text { infinite number of fractions } \\
\text { between any pair of fractions, } \\
\text { no matter how close they are. }\end{array}$ & $\begin{array}{l}\text { Iara: Yes, then I was subtracting,[...] then I } \\
\text { stopped there between } 33 \text { and [...] } 34 \text { which almost } \\
\text { gets there to arrive at } 496 \text { and } 33 \text { will arrive at } 512 \text {, } \\
\text { then I had to put a number in the middle, then I got } \\
33.5 \text { and started subtracting until I arrived at } 33.3 \\
\text { and realized that it had gone over } 20 \text { cents, then I } \\
\text { started subtracting again. But I was very close. [...] } \\
\text { then working with approximate data 16.67 } \\
\text { approximately of the } 14 \text { reais coffee and } 33.33 \text { of } \\
\text { the other... since it is a decimal. }\end{array}$ \\
\hline & $\begin{array}{l}\text { Relative thinking and } \\
\text { measurement }\end{array}$ & $\begin{array}{l}\text { Iara: Her (Bia's) result was more exact because } \\
\text { she used the fractionl/3. [...] if it were an exact }\end{array}$ \\
\hline
\end{tabular}




\begin{tabular}{|c|c|c|}
\hline & $\begin{array}{l}\text { Approximation principle: how to } \\
\text { decide the necessary precision } \\
\text { for a determined context. }\end{array}$ & $\begin{array}{l}\text { number then I think that Bia's result is more } \\
\text { correct. }\end{array}$ \\
\hline & $\begin{array}{l}\text { Relative thinking } \\
\text { (multiplicative) } \\
\text { Percentage Representation. }\end{array}$ & $\begin{array}{l}\text { Ada: If I find for } 1 \mathrm{~kg}[\ldots] \text { how many grams of each } \\
\text { type [...] by } 50 \text { (total mix). } \\
\text { Cléa: That's why she used percentages. }\end{array}$ \\
\hline & $\begin{array}{l}\text { Quantity and Covariation } \\
\text { Verbalize and Symbolize } \\
\text { mutable relations: highlight } \\
\text { important quantifiable } \\
\text { characteristics observing } \\
\text { whether the quantities are } \\
\text { changing or not under that } \\
\text { situation, and if they are, } \\
\text { observe changes directions } \\
\text { relations. Recognize that } \\
\text { variable quantities are not } \\
\text { always related. }\end{array}$ & $\begin{array}{l}\text { Tina: In the table it is possible to see that one } \\
\text { increases and the other decreases [...] even without } \\
\text { a multiplicative relationship, [...] because it had to } \\
\text { arrive at 50, the sum was } 50 . \text { [...] I think it's } \\
\text { proportional because I already knew that one had } \\
\text { more than the other. } \\
\text { Iara: On the straight line (representation), on the } \\
\text { top she places the prices and below the quantities. } \\
\text { There is a covariance relation. If we look at the } \\
\text { price, each space represents one real. On the line } \\
\text { below, it goes from } 50 \text { to } 0 \text { and from } 0 \text { to } 50 \text {. From } \\
\text { point A to point B, there are six spaces, then, each } \\
\text { space represents } 1 / 6 \text { of } 50 \text { or } 1 / 3 \text { of } 25 \text {. So, from the } \\
11 \text { reais position to the } 10 \text { reais position there must } \\
\text { be a decrease of } 1 / 3 \text { for bean } B \text { (1/3 of } 25) \text { and add } \\
1 / 3 \text { of bean A (1/3 of } 25) \text {. }\end{array}$ \\
\hline & $\begin{array}{l}\text { Up and down reasoning: the } \\
\text { strategy for this reasoning starts } \\
\text { by its initial fraction, goes } \\
\text { through a unitary fraction, a } \\
\text { unit, and, finally, arrives at the } \\
\text { desired fraction. }\end{array}$ & $\begin{array}{l}\text { Luiz: She }(\text { Ada }) \text { worked with another unit, another } \\
\text { whole. She reduced it to a smaller quantity (1 Kg) } \\
\text { to then find what was requested }(50 \mathrm{Kg}) \text {. She used } \\
\text { another whole }(1 \mathrm{~kg}) \text {. }\end{array}$ \\
\hline & $\begin{array}{l}\text { Unity flexibilization: To round } \\
\text { up before multiplying will } \\
\text { increase error by rounding up. }\end{array}$ & $\begin{array}{l}\text { Ada: I arrived there between } 33 \text { and } 34 \text {. I got it but } \\
\text { there was a difference of } 4 \text { cents, which at the end, } \\
\text { through multiplication, this difference disappears. } \\
\text { Luiz: With an approximation, the final amount } \\
\text { would give this difference. }\end{array}$ \\
\hline & $\begin{array}{l}\text { To solve problems without } \\
\text { algebraic resources, using only } \\
\text { one "reasoning", mobilizes } \\
\text { proportional reasoning. }\end{array}$ & $\begin{array}{l}\text { Tina: Many times, to place } x \text { and y may not make } \\
\text { any sense to the student. She needs to know who is } x \\
\text { and who is y. That's why proportional reasoning is } \\
\text { important even before using the letter [...] It is } \\
\text { important to see in the table what's fixed and what } \\
\text { varies. It's an important resource. }\end{array}$ \\
\hline $\begin{array}{l}\text { Professional } \\
\text { knowledge: } \\
\text { Pedagogical } \\
\text { mathematics }\end{array}$ & $\begin{array}{l}\text { The importance to discuss the } \\
\text { role of different types of } \\
\text { representations and context } \\
\text { adequacy. }\end{array}$ & $\begin{array}{l}\text { Iara: When I teach fractions I compare them with } \\
\text { decimals. The fraction is also to indicate an inexact } \\
\text { division. So this representation is also important. } \\
\text { Tina: Even with } 1 / 3 \text {, he will have to know how } \\
\text { many grams that represents. There is not a most } \\
\text { correct answer. It depends on the context. The scale } \\
\text { measures in decimals. }\end{array}$ \\
\hline & $\begin{array}{l}\text { Students' difficulties in learning } \\
\text { mathematics can be related to } \\
\text { teaching that emphasizes } \\
\text { resources and formal } \\
\text { representations. }\end{array}$ & $\begin{array}{l}\text { Clea: Many times the teaching of mathematics does } \\
\text { not promote the development of reasoning, } \\
\text { prioritizing rules and algorithms. Maybe the } \\
\text { difficulties students have lie on this fact. }\end{array}$ \\
\hline & $\begin{array}{l}\text { A problem can be solved } \\
\text { through resources and different } \\
\text { strategies. }\end{array}$ & $\begin{array}{l}\text { Clea: Something I learned a lot here was to look } \\
\text { for several ways to solve [a question]. Because I } \\
\text { was a lot like this, I saw only one way of doing } \\
\text { thing and had difficulty accepting that students did } \\
\text { differently. }\end{array}$ \\
\hline Vulnerability & $\begin{array}{l}\text { Difficulty to consider other } \\
\text { strategies and ways of thinking } \\
\text { mathematically. }\end{array}$ & $\begin{array}{l}\text { Laís: [It's difficult] to get rid of the devices, of the } \\
\text { algebra side. It's automatic to do it using rules, } \\
\text { systems. You "dig out" numbers in the problem and }\end{array}$ \\
\hline
\end{tabular}




\begin{tabular}{|c|c|c|}
\hline & & $\begin{array}{l}\text { immediately structures [the algorithm]. Many } \\
\text { times, you don't interpret the problem. }\end{array}$ \\
\hline & $\begin{array}{l}\text { Recognition of one practice that } \\
\text { prioritizes rules and algorithms. }\end{array}$ & $\begin{array}{l}\text { Iara: Sometimes we use formulas without thinking } \\
\text { about what we are doing. }\end{array}$ \\
\hline & $\begin{array}{l}\text { Confrontation of ideas and } \\
\text { opinions. }\end{array}$ & $\begin{array}{l}\text { Tânia: If you had to validate one or another } \\
\text { solution with the students, would make a difference } \\
\text { between this answer (Iara's answer) and this one } \\
\text { (Bia's answer)? } \\
\text { Bia: No, the two are correct. } \\
\text { Iara: (Bia's) was more exact because she used the } \\
\text { fraction } 1 / 3 \text {. [...] if it were an exact number then I } \\
\text { think Bia's is the most correct, not mine. }\end{array}$ \\
\hline $\begin{array}{l}\text { Sense of agency } \\
\text { and political } \\
\text { commitment }\end{array}$ & $\begin{array}{l}\text { The teacher needs to be } \\
\text { responsible for curriculum } \\
\text { management: selection and } \\
\text { organization of contents taking } \\
\text { into consideration time and } \\
\text { material conditions. }\end{array}$ & $\begin{array}{l}\text { Bia: We have an extremely extensive curricular } \\
\text { matrix, filled with contents! [...] We had to rethink } \\
\text { this matrix and work well with contents which are } \\
\text { more important. There's a lot to work and we end } \\
\text { up working with everything [but superficially]. } \\
\text { What's important for the student? }\end{array}$ \\
\hline
\end{tabular}

When CoPs participants analyzed their own solutions and justifications, it was possible to see that they created meaning for the elements that Lamon (2005) considers important for proportional reasoning, and which were the object of study in action 2 (considered little productive by CoPs' members in some moments, for contemplating discussions of texts unrelated to the practice). The meaning negotiations based on their own solutions and justifications (in action 4) promoted learning of the theory studied in action 2 and an articulation with the teacher's professional practice, revealing aspects of his/her professional identity.

The next section discusses practice elements which were common to CoP-PAEM and the other three CoPs, which promoted the development of their members' professional identity.

\section{CoPs' practice elements that promoted the development of the professional identity of their members}

Based on the analysis of the practices adopted by the four CoPs investigated in this study, we characterized eight elements that promoted the development of the professional identity of their members, namely: shared repertoires, reports and discussions on their pedagogical practices, the existence of a flexible and open work plan, the opportunity to discuss their written productions, vulnerability experiences, the search for balance in the sense of agency, connections between observations and empirical interpretations and a broader theoretical background, reports and discussions on previous meetings.

In the four $\mathrm{CoPs}$, shared repertoires included reification and participation aspects, namely: routines, mathematical and pedagogical concepts, classroom and teacher development courses stories, group discussions, and opinions about teaching and learning 
processes, which supported the domain of the communities. In one of the groups, the opportunity to produce manipulative material for the classroom and explore their potentials through the preparation and resolution of tasks associated with these materials was also part of the repertoire. The shared repertoire becomes more coherent not as an activity, symbol or specific artifact, but as part of a community practice in search for an articulated enterprise. It is a meaning negotiation resource and it reflects a story of mutual engagement in the community practice.

The opportunity to reflect on/discuss their pedagogical practices was another element in the context of the CoPs that promoted (future) teachers' learning. As the numbers of meetings increased, CoPs members were feeling more "comfortable" and secure to talk about facts that took place in the classroom (practicum), ask questions about mathematical contents or the teaching of these contents. These discussions led to choice of themes and texts to be studied and preparation of tasks to be used in the classroom, based on texts recommendations.

Teachers and future teachers had the opportunity to reflect on the application of these tasks in the classroom, and they were challenged to restructure them (task and application), if necessary. CoPs participants who listened to the reports expressed their understanding of the possibilities and limitations of those involved during the development of the tasks, indicating that they could have made similar choices, offering suggestions for new teaching practices. Such manifestations of recognition and solidarity legitimated the practice of these (future) teachers and posed some challenges to them, i.e., provoking them to rethink their own classroom practices as well as recognize, collectively, the existence of difficulties and therefore the need for new learning experiences.

According to the (future) teachers, this was a breakthrough, considering that to be able to develop a teaching practice they never experienced before, neither as students nor in their teacher development process, is very complex, constituting a teaching practice they only knew from a theoretical standpoint. It was also possible to verify that, besides being satisfied for being able to share experiences and doubts related to their teaching practice, this moment also promoted an approximation between (future) teachers and teacher educator, since they experience similar problems and dilemmas.

The existence of a flexible and open work plan promoted an approximation between (future) teachers and teacher educators, minimizing the distance that usually exists between university and school by valuing the singularities and professional practices of these (future) 
teachers. Actions, joint enterprises, dynamics and themes were always negotiated by the CoPs members in order to meet their desires and professional needs.

Another element within the context of the CoPs that promoted learning by teachers was the opportunity to discuss and reflect on their written productions, being committed to the justifications for their statements. During the solution of mathematical tasks, the (future) teachers could share different solution registers, procedures and strategies. As a result, they started valuing/recognizing the resolutions presented by their students. The process of meaning negotiation was organized around the reflection on the defined objectives, clarity of the statements and the exploration of the potentials of a determined task potential, resulting in reifications through the participation of members of the community thus leading to learning. The possibility to question and be questioned favored the process of meaning negotiation and the creation of a communicative space.

By discussing their productions and knowledge about their profession (future) teachers experienced vulnerability and were challenged to question their certainties and convictions. This helped them develop a sense of agency, i.e., they had the opportunity to conciliate what must be done and what needs to be mobilized in relation to themselves (knowledge, beliefs, feelings, emotions), taking into consideration context conditions (access, resources, support). These experiences helped them to question and get involved in meaning negotiations, i.e., they helped them guide their own learning process through full participation and processes of reification.

Situations of vulnerability helped CoPs members to understand that they are inherent conditions of the professional practice, and that they originate from "the relational nature of the profession and is related to the ethical character of the relation" (OLIVEIRA; CYRINO, 2011), once they may affect the efficacy of the actions and decisions of the teacher, which will always be subjected to criticism and judgements. However, it is possible to balance their sense of agency and minimize the negative feelings generated during the process.

During CoPs practices, members had opportunities to establish connections between observations and empirical interpretations and a broader theoretical background. By interacting with others and using their knowledge and pedagogical practices, (future) teachers felt the need to resort to a theoretical background to trigger new meaning negotiations and, therefore, new learning experiences. By learning new forms of reasoning (from colleagues or texts), the participants had the opportunity to respect and validate the information mobilized during the meetings. This practice associated with the long-term coexistence promoted the establishment of relationships of trust among the members. 
To reflect on the teacher development process based on reports and discussions of previous meetings was one practice element adopted by the CoPs which allowed (future) teachers to accept the challenge to provoke communicative interactions through inquisitive questionings in the study groups and in the classrooms. The statements of some (future) teachers show that this type of development, which privileges the work developed from the articulation of enterprises defined by the community and creates conditions for the recognition of experiences and the sharing of repertoires and knowledge, allows the meaning negotiations and therefore the development of learning and professional identity experiences.

\section{Final considerations}

The participation of (future) teachers in these educational activities was marked by the development of "mutual engagement" and a "participation identity" (WENGER, 1998). In this perspective, Wenger, McDermott and Snyder (2002, p. 28) state that "a strong community promotes interactions and relationships based on mutual respect and trust. It fosters the voluntary action of sharing ideas, exposing our own ignorance, making difficult questions and listening carefully". The changes identified during the CoPs' practice and the establishment of a routine of pondered and systematic reflection presented themselves as key points to support the development of the teacher's professional identity.

The search for an approximation between the university and the school and the opportunity of teachers and future teachers to work collectively, prepare/organize possible materials and works to be developed in the classroom, share experiences, study and discuss mathematical concepts, work individually or in small groups solving problems and working on tasks to discuss resolutions collectively, participate actively in their development processes, expose their limitations without feeling embarrassed marked the practice of these CoPs and created a fertile soil for the constitution and strengthening of their professional knowledge.

Aspects such as respect, trust, challenge, solidarity, enterprises negotiation, dynamics and actions, valorization of singularities and the teachers' professional practices also constituted a fertile soil for the development of the professional identity of these professionals and for the cultivation and maintenance of these groups through the establishment of relationships between teacher educators and developing teachers.

Teacher education proposals that value the experiences, repertoires and knowledge of those involved, as well as that assume that learning takes place through meaning negotiations, including aspects as those mentioned, are more adequate to the teacher development process. 


\section{Acknowledgements}

The author would like to thank the participants who voluntarily contributed to the completion of this study, the Coordination of Improvement of Higher Education Personnel (CAPES/Brazil) and the Council for Scientific and Technological Development (CNPq/Brazil) by financial support.

\section{References}

BEIJAARD, D.; MEIJER, P. C.; VERLOOP, N. Reconsidering research on teachers' profesional identity. Teaching and teacher education, New York, v. 20, n. 2, p. 107-128. 2004.

CAI, J.; SUN, W. Developing Students' Proportional Reasoning: a Chinese Perspective. In: LITWILLER, B.; BRIGHT, G. (Ed.). Making sense of fractions, ratios and proportions: 2002 Yearbook. 2 ed. Reston: National Council of Teachers of Mathematics, 2002. p. $195-205$.

CRAMER, K.; POST, T.; BEHR, M. Interpreting Proportional Relationships. Mathematics Teacher, Reston, v. 82, n. 6, p. 445-452, sep. 1989.

CYRINO, M.C.C.T. Comunidades de prática de professores como espaço de investigação sobre a formação de professores de matemática. In: BATISTA, I. L.; SALVI, R. F. (Org.). Pós-graduação em ensino de ciências e educação matemática: um perfil de pesquisas. Londrina: EDUEL, 2009. p. 95110.

CYRINO, M. C. C. T.; CALDEIRA, J. S. Processos de negociação de significados sobre pensamento algébrico em uma comunidade de prática de formação inicial de professores de Matemática. Revista Investigações em Ensino de Ciências, Porto Alegre, v.16, n.3, p. 373-401, dez. 2011.

GARCIA, T. M. R. Identidade Profissional de Professor de Matemática em uma Comunidade de Prática. 2014. 161 f. Tese (Doutorado em Ensino de Ciências e Educação Matemática) - Centro de Ciências Exatas, Universidade Estadual de Londrina, Londrina, 2014.

GRAVEMEIJER, K. P. E.; COBB, P. Design research from the learning design perspective. In: VAN DEN AKKER, J. J. H.; et al. (Ed.). Educational design research. London: Routledge, 2006. p. 17-51.

GRAVEN, M.; LERMAN, S. Book Review. Journal of Mathematics Teacher Education, Netherlands, v.6, n.2, p.185-194, abr./jun. 2003.

GRAVEN, M. Mathematics teacher retention and the role of identity: Sam's story. Pythagoras, Port Elizabeth, n. 61, p. 1-10, jun. 2005.

JAWORSKI, B. Situating Mathematics Teacher Education in a Global Context. In: BENARZ, N. et al. (Ed.). International Approaches to Professional Development of Mathematics Teachers. 1 ed. Ottawa: University of Ottawa Press, 2011. p. 2-50.

KARPLUS, R.; PULOS, S.; STAGE, E. K. Early adolescents' proportional reasoning on 'rate' Problems. Educational Studies in Mathematics, New York, v.14, n.3, p. 219-233, aug.1983.

KELCHTERMANS, G. Who I am in how I teach is the message: self-understanding, vulnerability and reflection. Teachers and Teaching: theory and practice, New York, v. 15, n 2, p. 257-272, may. 2009. 
KIEREN, T. E. The rational number construct - Its elements and mechanism. In: KIEREN, T. E. (Ed.), Recent Research on Number Learning. Columbus: ERIC/SMEAC, 1980. p. 125-150.

KRAINER, K. Teams, communities \& networks. Journal of Mathematics Teacher Education, Netherlands, v.6, n.2, p. 93-105, abr/jun. 2003.

LAMON, S. J. Teaching fractions and ratios for understanding: Essential content knowledge and instructional strategies for teachers. 2th edition. Mahwah: Lawrence Erlbaum Associates, 2005.

LAVE, J.; WENGER, E. Situated learning: legitimate peripheral participation. Cambridge: Cambridge University Press, 1991.

LESH, R.; POST, T.; BEHR, M. Proportional Reasoning. In: HIEBERT, J.; BEHR, M. (Ed.). Number Concepts and Operations in the Middle Grades. Reston: Lawrence Erlbaum \& National Council of Teachers of Mathematics. 1988. p. 93-118.

LLINARES, S. Participation and reification in learning to teach: the role of knowledge and beliefs. In: LEDER, G. C.; PEHKONEN, E.; TÖRNER, G. (Org.), Beliefs: a hidden variable in mathematics education?. Dordrecht: Kluwer Academic Publishers, 2002. p. 195-209.

NAGY, M. C.; CYRINO, M. C. C. T. Aprendizagens de professoras que ensinam Matemática em uma Comunidade de Prática. Revista da FAEEBA - Educação e Contemporaneidade, Salvador, v. 23, n.41, p.149-163, jan/jul 2014.

OLIVEIRA, L.M.C.P. Aprendizagens no empreendimento estudo do raciocínio proporcional. 2014. 209f. Dissertação (Programa de Pós-Graduação em Ensino de Ciências e Educação Matemática) - Centro de Ciências Exatas, Universidade Estadual de Londrina, Londrina, 2014.

OLIVEIRA, H. M.; CYRINO, M.C.C.T. A formação inicial de professores de Matemática em Portugal e no Brasil: narrativas de vulnerabilidade e agência. Interacções, Lisboa, v. 7, p. 104-130, ago. 2011.

PONTE, J. P.; CHAPMAN, O. Preservice mathematics teachers' knowledge and development. In: ENGLISH, L. D. (Ed.). Handbook of international research in mathematics education. 2. ed. New York: Routledge, 2008. p. 225-263.

POST, T.; CRAMER, K.; HAREL, G.; KIERNEN, T.; LESH, R. Research on rational number, ratio and proportionality. In: Proceedings of the twentieth annual meeting of the north american chapter of the international group for the psychology of mathematics education, PME-NA XX , Raleigh, 1998. Proceedings... Raleigh: ERIC, 1998. v.I. p.89-93.

SHULMAN, L. S. Those who understand: knowledge growth in teaching. Educational Researcher, Washington, v.15, n.2, p.4-14, feb. 1986.

SHULMAN, L. S. Knowledge and teaching: foundations of the new reform. Harvard Educational Review, Cambridge, v.57, n.1, p.1-22, feb. 1987.

SIMON, M. A. The challenges of mathematics teacher education in an era of mathematics education reform. In: JAWORSKI, B; WOOD, T. (Ed.). The international handbook of mathematics teacher education: mathematics teacher educator as a developing profissional. Rotterdam: Sense Publisher, 2008. p. 17-29.

SOWDER, J. T. The mathematical education and development of teachers. In: LESTER, F. (Ed.). Second handbook of research on mathematics teaching and learning, Reston: NCTM, 2007. p. 157-224. 
WENGER, E. Communities of practice: learning, meaning and identity. New York: Cambridge University Press, 1998.

WENGER, E.; MCDERMOTT, R.; SNYDER, W. M. Cultivating communities of practice. Boston: Harvard Business School Press, 2002.

Submetido em Julho de 2015. Aprovado em Setembro de 2015. 